\title{
BANK SAMPAH DAN PEMBUATAN ARENA SELFIE DALAM PEMANFAATAN SAMPAH PLASTIK PADA MASYARAKAT DESA (Studi pada Masyarakat Desa Kenongo Kota Sidoarjo)
}

\author{
Sumartik $^{1}$, Lilik Indayani ${ }^{2}$ \\ ${ }^{1,2}$ Program Studi Manajemen, Fakultas Bisnis Hukum dan Ilmu Sosial \\ Universitas Muhammadiyah Sidoarjo \\ Email:sumartik@umsida.ac.id
}

\begin{abstract}
Kenongo Village is a densely populated village in the city of Sidoarjo which has many rivers. Habits of people who like littering give off a bad smell. The 'Sekar Kenanga' Garbage Bank is an alternative waste treatment facility conducted by Kenongo villagers. Processing waste does not only produce different goods but also has economic value that can increase the economic independence of the community and create an arena where selfies from recycling plastic waste are also carried out by the community from processed plastic waste. This study aims to provide an overview of the role of the 'Sekar Kenanga' garbage bank and a selfie-making place that utilizes plastic waste in Kenongo Village, either from collecting garbage in a garbage bank or from collecting plastic waste in a river near the village. The method used is descriptive qualitative. Data obtained through interviews with key informants such as the Village Head, the management of the waste bank, members of the waste bank, youth of youth clubs and the community who are not members of the waste bank 'Sekar Kenanga" and also not the sanitation department of Tulangan sub-district. Observation in the field was carried out by providing various training in the processing of souvenir creations and accessories from plastic waste and decoration making techniques for selfie places with nuanced appeal to maintain the cleanliness of rubbish. Activities in data analysis are data reduction, data organizing and interpretation. The results showed that from the institutional aspects of the village, the Sekar Kenanga'urut waste bank and the village community empowerment program, the financing aspect, is still needed optimally managing the waste bank financial sector with greater profits, and the application of community participation has been as good and active as is they know that they don't understand all about the importance of making garbage banks and selfiemaking places, it is only limited to selling garbage to the 'Sekar Kenanga' waste bank.
\end{abstract}

Keywords: PKK, Empowerment, Sekar Kenanga Garbage Bank, Spot Selfie.

\begin{abstract}
Abstrak, Desa Kenongo merupakan desa padat penduduk di kota Sidoarjo yang banyak terdapat sungai disekitar pemukiman. Kebiasaan masyarakat yang suka membuang sampah sembarangan seringkali menciptakan bau busuk yang mengganggu aktivitas masyarakat. Bank Sampah 'Sekar Kenanga' merupakan tempat alternatif pengolahan sampah yang dilakukan oleh warga desa Kenongo. Pengolahan sampah tidak saja diolah menjadi barang yang berbeda namun bernilai ekonomis yang dapat menambah kemandirian ekonomi masyarakat serta pembuatan arena spot selfie dari daur ulang sampah plastik juga dilakukan masyarakat dari hasil olahan sampah plastik. Penelitian ini bertujuan untuk memberikan gambaran mengenai peran bank sampah 'Sekar Kenanga'dan pembuatan spot selfie yang memanfaatkan sampah plastik di Desa Kenongo baik dari pengumpulan sampah di bank sampah ataupun dari penjaringan sampah plastik di sungai sekitar pemukiman desa. Metode yang digunakan adalah deskriptif kualitatif. Data didapatkan melalui wawancara terhadap informan kunci seperti Kepala Desa, pengurus bank sampah, anggota bank sampah, remaja karang taruna dan masyarakat bukan anggota bank sampah 'Sekar Kenanga"serta unsur dinas kebersihan dari kecamatan Tulangan. Observasi di lapangan dilakukan dengan memberikan berbagai pelatihan pengolahan kreasi souvenir dan aksesories dari sampah plastik dan teknik pembuatan hiasan untuk spot selfie yang bernuansa himbauan menjaga kebersihan sampah. Aktivitas dalam analisis data yaitu data reduction, data organization dan interpretation. Hasil penelitian menunjukkan dari aspek kelembagaan desa, bank sampah 'Sekar Kenanga'turut serta dalam program pemberdayaan masyarakat desa, Aspek pembiayaan, masih diperlukan pengeloaan keuangan bank sampah secara optimal dengan keuntungan yang lebih besar, dan apek peran serta masyarakat sudah baik dan aktif tetapi mereka belum faham semua tentang arti penting pengolahan bank sampah dan pembuatan spot selfie, hanya terbatas menjual sampah ke bank sampah 'Sekar Kenanga'.
\end{abstract}

Kata Kunci: Kelompok PKK, Pemberdayaan, Bank Sampah Sekar Kenanga, Spot Selfie. 


\section{PENDAHULUAN}

Sampah plastik menjadi masalah yang serius dalam aktivitas kehidupan manusia. Jumlah sampah yang meningkat seiring dengan bertambahnya jumlah penduduk dan berkurangnya kesadaran masyarakat akan pentingnya kebersihan lingkungan. Salah satu bentuk upaya yang dilakukan oleh pemerintah Kota Sidoarjo dalam penanganan sampah adalah membuat TPST (pengolahan sampah terpadu) di sejumlah desa, membangun TPA (tempat pembuangan akhir) di beberapa kecamatan dan memaksimalkan pengolahan sampah plastik.

Pemanfaatan sampah di Sidoarjo termaktub dalam Peraturan Daerah Kabupaten Sidoarjo Nomor 6 tahun 2012 yang menyebutkan bahwa pertambahan penduduk dan perubahan pola konsumsi masyarakat menimbulkan bertambahnya volume, jenis dan karakteristik sampah yang beragam, untuk itu pengelolaan sampah harus dilakukan secara komprehensif dan terpadu dari hulu ke hilir sesuai dengan prinsip yang berwawasan lingkungan sehingga tidak menimbulkan dampak negatif terhadap kesehatan asyarakat dan lingkungan, memberikan manfaat ekonomi serta dapat mengubah perilaku masyarakat. Merujuk pada peraturan daerah tersebut maka peran bank sampah dirasakan masyarakat sangat bernilai penting.

Desa Kenongo merupakan desa di kecamatan Tulangan Kota Sidoarjo dengan jumlah penduduk 1.056 jiwa yang berbatasan dengan desa gelang, desa kepatihan, desa kebaron dan desa Kepadangan. Dengan meningkatnya jumlah penduduk desa Kenongo maka secara langsung berdampak pada meningkatnya jumlah sampah rumah tangga yang dihasilkan. Posisi desa yang banyak dilewati sungai menjadi sasaran empuk masyarakat dengan kesadaran yang kurang untuk selalu membuang sampah sembarangan, akibatnya sampah menumpuk di tepi tepi sungai yang alirnya kurang mengalir deras sehingga menimbukan aroma bau busuk yang menyengat dan mengganggu aktivitas masyarakat desa seperti yang terlihat di gambar 1 .

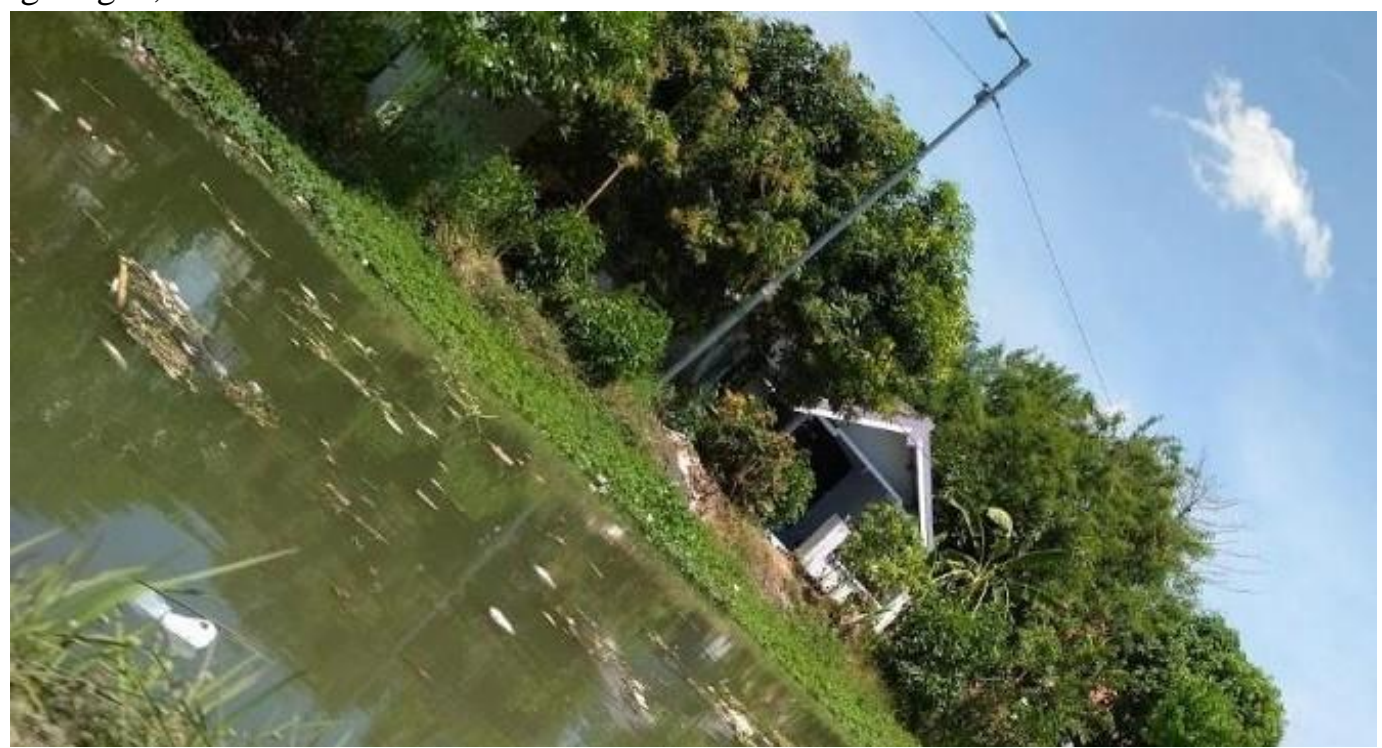

Gambar 1. Daerah pemukiman warga desa yang dekat dengan sungai penuh sampah 
Menindaklanjuti solusi permasalahan sampah di desa Kenongo adalah mendorong kesadaran masyarakat akan bahaya sampah plastik bagi kesehatan dan pentingnya pemberdayaan masyarakat untuk mengolah sampah plastik melalui terbentuknya Bank Sampah 'Sekar Kenanga' oleh kader-kader PKK RT di desa Kenongo serta pentingnya himbauan kepada masyarakat desa Kenongo untuk tidak mengulangi kebiasaan buruk mereka untuk membuang sampah sembarangan melalui pembuatan arena selfie dari olahan sampah plastik yang ditempatkan di sepanjang jalan desa Kenongo yang rawan dijadikan tempat membuang sampah. Pembuatan arena/spot selfie ini juga dilengkapi dengan tulisan

yang bernada himbauan kepada masyarakat untuk selalu menjaga kebersihan. Hal ini diharapkan mampu meningkatkan kesadran dan rasa memiliki untuk selalu menjaga kebersihan lingkungan mereka dengan mengabadikan moment keindahan di galeri foto masyarakat desa Kenongo. Berdasarkan uraian diatas, maka penelitian ini bertujuan untuk memberikan gambaran mengenai peran bank sampah dan pembuatan arena selfie dalam pemanfaatan sampah plasik pada masyarakat desa Kenongo.

\section{METODE PENELITIAN}

Penelitian ini merupakan penelitian diskriptif kualitatif, yaitu penelitian yang bermaksud mendeskripsikan fenomena yang terjadi berdasarkan hasil eksplorasi bank sampah 'Sekar Kenanga" dan pembuatan arena selfie dalam pemanfaatan sampah plastik pada masyarakat desa Kenongo. Data didapatkan melalui wawancara terhadap informan kunci seperti Kepala Desa, pengurus bank sampah, anggota bank sampah, remaja karang taruna dan masyarakat bukan anggota bank sampah 'Sekar Kenanga"serta unsur dinas kebersihan dari kecamatan Tulangan. Observasi di lapangan dilakukan dengan memberikan berbagai pelatihan pengolahan kreasi souvenir dan aksesories dari sampah plastik dan teknik pembuatan hiasan untuk spot selfie yang bernuansa himbauan menjaga kebersihan sampah. Aspek-aspek manajemen pengelolaan persampahan digunakan untuk memahami peranan bank sampah dalam proses pengelolaan sampah plastik dan pembuatan arena selfie dalam pemanfaatan sampah plastik yaitu aspek kelembagaan, pembiayaan serta peran serta masyarakat. Aktivitas dalam analisis data yaitu data reduction, data organization dan interpretation.

\section{HASIL DAN PEMBAHASAN}

Bank Sampah 'Sekar Kenanga' pada masyarakat desa Kenongo

Pengelolaan Bank sampah di kota Sidoarjo sudah mulai dirintis di tahun 2012 dan dituangkan dalam rapat kerja tahunan. Pengelolaan sampah di masyarakat juga berdasarkan asas tanggung jawab, berkelanjutan, manfaat, keadilan, kesadaran, kebersamaan, keselamatan dan keamanan serta bernilai ekonomi. Adapun pengelolaan sampah bertujuan untuk meningkatkan kesehatan masyarakat dan kualitas lingkungan serta menjadikan sampah sebagai sumber daya. Adapun misi bank sampah 'Sekar Kenanga' adalah:

1. Mengurangi jumlah sampah yang dibuang ke TPA

2. Mengurangi jumlah sampah yang dibuang di sungai desa Kenongo

3. Mendayagunakan sampah terutama sampah plastik menjadi barang bernilai guna dan ekonomis.

4. Menciptakan lingkungan yang bersih dan sehat

5. Pemberdayaan masyarakat terutama kader PKK.

6. Menciptakan lapangan pekerjaan dan membudayakan ekonomi masyarakat desa kenongo dari pengolahan sampah plastik.

7. Membangun himbauan sadar lingkungan dengan tidak membuang sampah sembarangan dengan cara pembuatan arena selfie dengan pemanfaatan sampah plastik.

Dengan demikian ibu-ibu rumah tangga yang biasanya hanya membuang sampah, membakar serta mencemplung sembarangan di sungai, mereka sudah mulai dapat memilah sampah dan membawanya ke bank sampah 'Sekar Kenanga' untuk dijual yang sekaligus menjadi tabungan. Kemudian dari 
banksampah dipilah lagi, mana yang harus dijual kepada pengepul sampah dan mana yang dapat diolah masyarakat untuk produk yang lebih bermanfaat dan bernilai ekonomis.
Adapun kegiatan ibu-ibu PKK dalam bank sampah Sekar kenanga dapat ditunjukkan dalam gambar 2 dan gambar 3 dibawah in

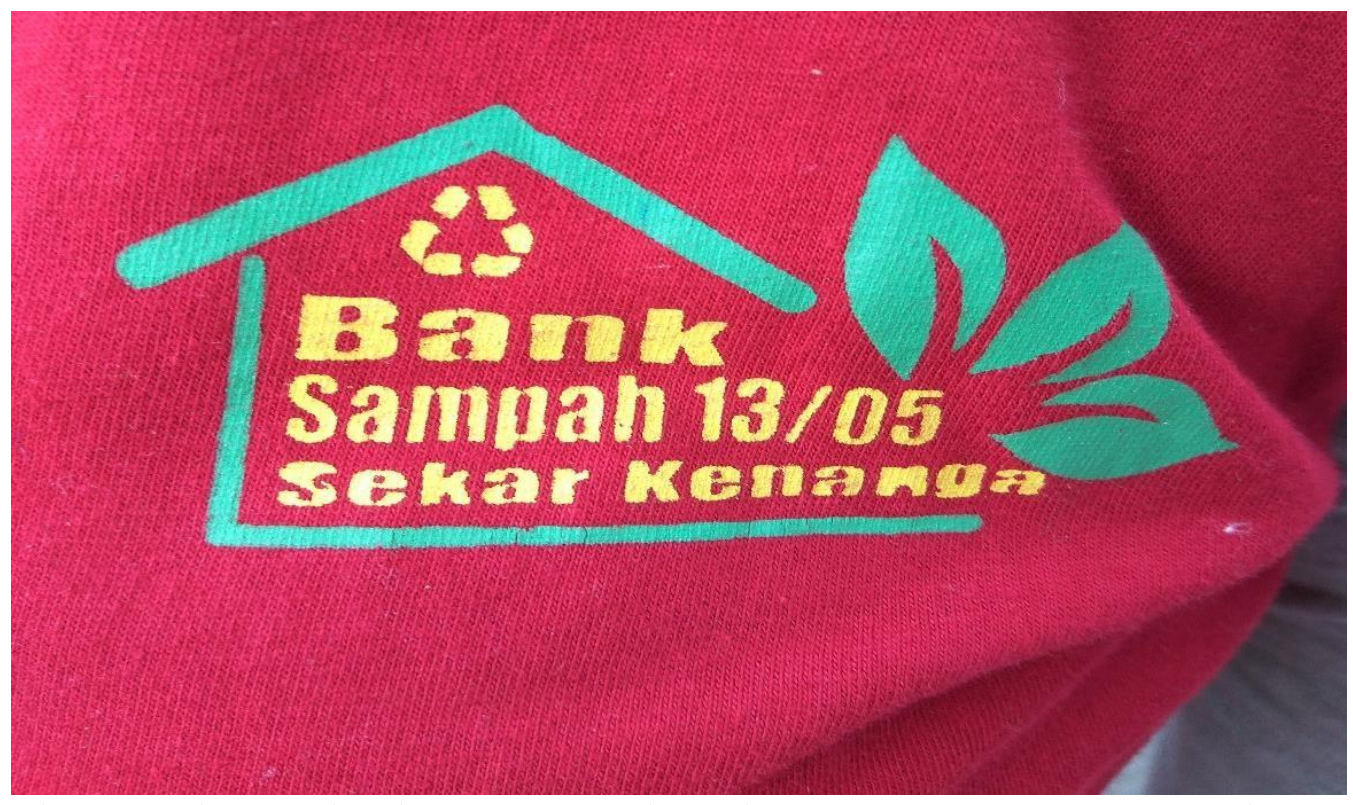

Gambar 2. Bank Sampah Sekar Kenanga Kelompok PKK RT.13 Desa Kenongo-Tulangan

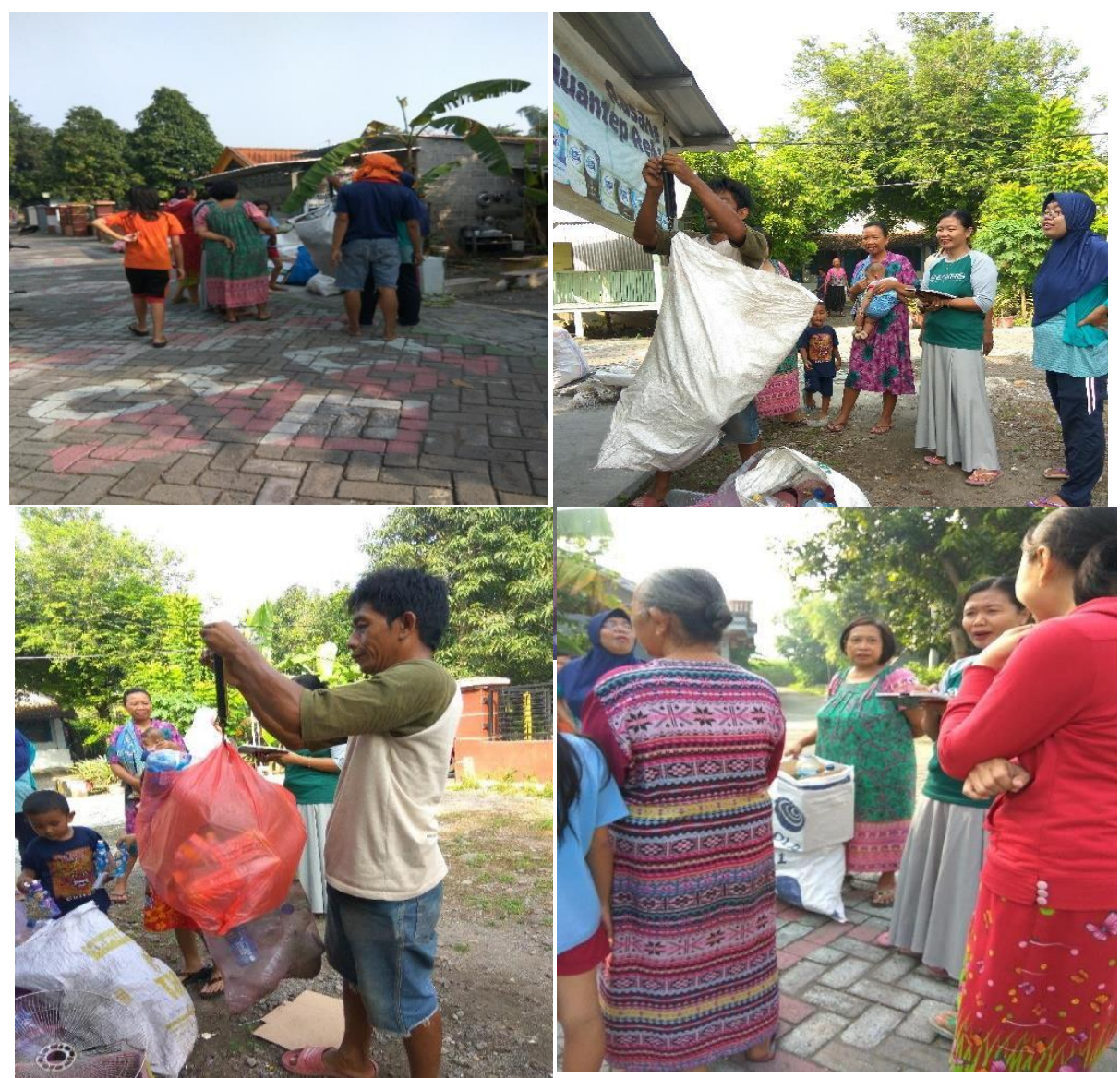

Gambar 3: Kegiatan menimbang sampah di tempat Bank Sampah 


\section{ASPEK KELEMBAGAAN}

Bank Sampah 'Sekar Kenanga' merupakan lembaga masyarakat yang berdiri atas inisiatif Kepala Desa Kenongo dan masyarakat terutama kader-kader PKK yang ada di desa. Kader PKK RT 13 sebagai pelopor pendirian bank sampah “ Sekar Kenanga'. Secara kelembagaan, bank sampah sebagai jelmaan pasal 4 UU No .6 Peraturan Daerah Sidoarjo tahun 2012 tentang pengeloaan sampah. Secara kelembagaan, bank sampah 'Sekar Kenanga' dinilai sebagai lembaga yang turut serta mengelola persampahan sekaligus sebagai wadah pemberdayaan ibu-ibu PKK. Bank sampah 'Sekar Kenanga merupakan wadah untuk membina dan melatih serta mengolah sampah plastik menjadi barang bernilai guna dan ekonomis. Bank Sampah ' Sekar Kenanga' didirikan pada tahun 2017 dengan beranggotakan kader-kader PKK dan masyarakat sejulah 450 orang dengan syarat menyerahkan fotocopy KTP dan Kartu Keluarga serta uang pendaftaran Rp. 5.000,- yang digunakan sebagai setoran pokok Rp. 4.000,- dan Rp.1.000,- untuk pengganti buku tabungan.

Sarana dan prasarana yang dimiliki bank sampah 'Sekar Kenanga' adalah timbangan, buku kas untuk mencatat jumlah sampah dan nominal tabungan dari anggota, buku tabungan yang diberikan kepada anggota bank sampah. Gerobak sampah, alat gunting, kuas, cat, pisau, lem yang digunakan sebagai sarana pembuatan produk baru hasil pengolahan sampah plastik yaitu bunga plastik, pot, dsb yang dipakai di arena spot selfie. Adapun pengurus dari bank sampah adalah kader-kader PKK terutama RT 13 yang dijadikan kepala desa sebagai proyek percontohan RT yang asri dan sadar lingkungan. Ketua Bank Sampah adalah ibu Ketua RT 13, yang bertanggung jawab terhadap kegiatan unit/ kelompok bank sampah yang menkoordinir seluruh anggotanya. Sekretaris diambilkan dari warga, yang bertugas untuk mencatat proses penimbangan dan buku kas serta di buku tabungan anggota serta melakukan pencatatan administrasi anggota kelompok bank sampah. Bendahara juga diambilkan dari warga, yang bertanggung jawab melakukan pencatatan pembukuan transaksi pembelian sampah termasuk pembayaran untuk berbagai kegiatan bank sampah. Dalam proses penimbangan dan pemilahan sampah, warga masyarakat selalu bersama sama dan saling membantu dalam mendukung tugas bendahara dan sekretaris.

\section{ASPEK PEMBIAYAAN}

Kegiatan pengelolaan bank sampah ini dilakukan dengan cara mengumpulkan sampah rumah tangga, dipilah dirumah masing-masing warga, sesuai komposisi sampah plastik yang dapat dijual dan selanjutnya warga membawa sampah mereka dengan bantuan gerobak sampah di tempat bank sampah ' Sekar Kenanga'. Sampah dihargai Rp. 6000,-/kg. Saat ini omzet bank sampah kurang lebih Rp.

3.000 .000 - 4.500 .000 per bulan. Biaya gaji pengurus $\mathrm{Rp} 500.000$ ( ketua, sekretaris, bendahara dan pengangkut sampah). Adapun perolehan hasil penjualan sampah pada bulan desember 2019 di desa kenongo dapat dilihat dalam tabel 1 dibawah ini:

Tabel 1. Hasil penjualan sampah di Bank Sampah Sekar Kenanga Desa Kenongo pada bulan Desember 2019.

\begin{tabular}{llccr}
\hline No & Nama RT & $\begin{array}{c}\text { Total Sampah } \\
\text { per bulan }(\mathrm{kg})\end{array}$ & Harga Sampah/kg & \multicolumn{1}{c}{ Hasil penjualan (Rp) } \\
\hline 1 & RT 7 & 56 & 6000 & 336.000 \\
\hline 2 & RT 8 & 50 & 6000 & 300.000 \\
\hline 3 & RT 9 & 99 & 6000 & 594.000 \\
\hline 4 & RT 10 & 67 & 6000 & 402.000 \\
\hline 5 & RT 11 & 88 & 6000 & 528.000 \\
\hline 6 & RT 12 & 94 & 6000 & 564.000 \\
\hline 7 & RT 13 & 215 & 6000 & 1.290 .000 \\
\hline 8 & RT 14 & 42 & 6000 & 252.000 \\
\hline & TOTAL & & & 4.266 .000 \\
\hline
\end{tabular}


Meskipun demikian, keuntungan tersebut masih relatif kecil bagi bank sampah karena kegiatan ini semata memberikan keuntungan yang besar bagi kelompoknya berupa tabungan bank sampah yang dapat diambil menjelang hari raya idul fitri jika dibandingkan dengan biaya operasional untuk pengolahan bank sampah menjadi arena selfie yaitu pembelian perkakas cat, kuas, gunting, lem, paku, palu dsb.

Permasalahan lainnya yaitu dengan harga sampah oleh pengepul sampah yang fluktuatif, sehingga seringkali warga yang menjadi anggota bank sampah melirik harga pengepul lain di sekitar desa. Masalah yang cukup mengganjal adalah diberlakukannya harga sampah dengan ukuran kg saja, sementara tidak ada harga sampah berdasarkan nilai ekonomis barang tersebut yang tentu saja sangat menguntungkan pihak pengepul sampah dan merugikan bank sampah.

\section{Aspek Peran Serta Masyarakat}

Dari 1.056 jiwa masyarakat desa sekitar 450 jiwa yang terdaftar keikutsertaan di bank sampah 'Sekar Kenanga'. Hal ini menandakan bahwa peran serta masyarakat sudah cukup tinggi, dikarenakan dalam 1 rumah tangga, terdapat 1-2 orang yang ikut menjadi anggota bank sampah. Dari tahun 2017 awal terbentuknya bank sampah sampai sekarang jumlah anggota terus meningkat hal ini membuktikan tingkat kesadaran masyarakat akan pentingnya pengolahan sampah plastik sudah meningkat. Bank sampah sekar kenanga telah memberdayakan semua unsur masyarakat dari ibu-ibu PKK, karang taruna, bapak-bapak untuk memilah sampah dan mendaur ulang sampah sehingga adanya kesadaran akan manfaat ekonomis dari bank sampah sebagai tambahan penghasilan.

Nilai penjualan sampah yang fluktuatif dan belum adanya pemahaman yang sama anatara warga masyarakat menengah ke atas, seakan kegiatan ini adalah kegiatan pemulung dan tercibirkan. Kendala seperti ini harus terus menerus dilakukan pendekatan dan sosialisasi dan pembuktian bahwa pengolahan sampah platik dari bank sampah dan pembuatan arena selfie mampu memberikan manfaat dan keindahan lingkungan bagi desa Kenongo. Mekanisme pemilahan sampah dilakukan di rumah masing-masing warga dan dikumpulkan di bank sampah setiap hari minggu jam 10.00 11.00 wib dengan membawa sampah serta buku tabungan. Selanjutnya dilakukan penimbangan oleh pengepul sampah, pihak sekretaris melalukan pencatatan administratif dan pihak bendahara membukukan pencatatan keuangan di kas besar dan buku tabungan warga.

Kendala operasional yang dialami bank sampah yaitu kurangnya tempat atau wadah khusus sampah yang tidak dijual ke pengepul tetapi diolah sendiri menjadi barang bernilai ekonomis dan layak jual serta pengisi pembuatan arena selfie dari pemanfaatan sampah plastik. Sebagian besar tempat penyimpanan masih menggunakan area poskamling atau bangunan kosong di RT 13. Hal inilah yang menjadi tugas dari aparat desa dan masyarakat untuk memikirkan gudang sebagai prasarana yang harus ada dan mempunyai peran penting untuk menjaga kualitas sampah tetap kering dan terlindung dari hujan.

\section{PEMBUATAN ARENA/SPOT SELFIE DARI PEMANFAATAN SAMPAH PLASTIK}

Kurangnya kesadaran masyarakat untuk 'main cemplung' sampah rumah tangga mereka di kawasan sekitar sungai pemukiman warga, selain menimbulkan bau busuk juga menimbulkan pemandangan tidak sedap mata. Membuat arena spot selfie di Wilayah Desa Kenongo dari bahan daur ulang sampah plastik, akan menjadi arena spot tersendiri bagi warga desa dalam menampung hobi selfie yang lagi populer sekaligus memberi pesan moral bagi warga sekitar untuk selalu menjaga lingkungan dengan membuang sampah pada tempatnya. Kegiatan ini sangat disukai anak muda, daripada mereka nongkrong dan pergi jauh dari rumah mereka untuk berfoto ria, lebih baik mereka berfoto di desa sendiri. Hal ini secara otomatis membawa keindahan desa dan rasa sungkan untuk membuang sampah di kawasan tersebut.

Mekanisme yang dilakukan oleh bank sampah adalah memilah sampah plastik yang akan digunakan untuk menghias spot selfie dan 
tidak langsung dijual ke pengepul. Mereka memilah, membersihkan, menjemur dan menggunting, mengelem, serta mengecat aneka warna menjadi hiasan pot, bunga plastik, daun yang kemudian dipasang di daerah yang sudah ditentukan menjadi arena selfie. Kemudian arena tersebut dihias dengan tulisan-tulisan yang berupa himbauan untuk tidak membuang sampah pada sungai ataupun tempat yang tidak semestinya. Ternyata pembuata arena selfie memberikan manfaat besar untuk keindahan desa Kenongo. Masyarakat semakin betah, lingkungan menjadi sehat dan asri. Hal ini dapat ditunjukkan pada gambar 4 dibawah ini.
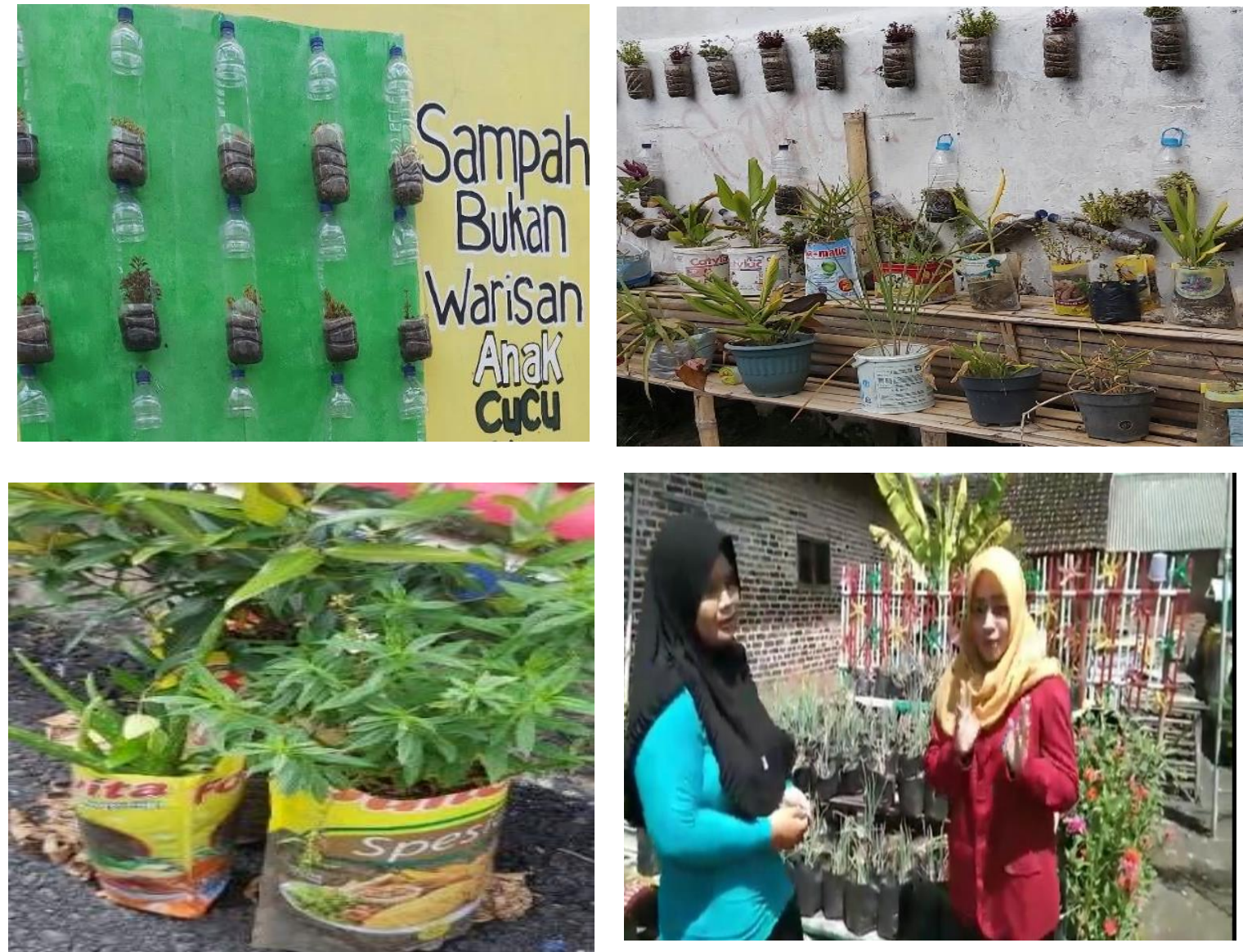

Gambar. 4. Spot Selfie Desa Kenongo dari sampah bekas botol plastik dan aneka kemasan

\section{SIMPULAN DAN SARAN}

Program pengelolaan bank sampah 'Sekar Kenanga' menjadi solusi bagi pemerintah, aparat desa, dan masyarakat untuk mengurangi jumlah sampah rumah tangga yang terus meningkat seiring jumlah pertumbuhan penduduk desa Kenongo. Dalam Bank sampah terdapat pendidikan untuk memilah sampah, dan mengubah perilaku masyarakat untuk mendaur ulang sampah menjadi barang bernilai ekonomis serta membuat arena selfie berpesan moral himbauan menjaga kebersihan untuk menumbuhkan kesadaran warga dalam menjaga kebersihan lingkungan. Kendala yang dihadapi oleh bank sampah adalah aspek pembiayaan mengenai harga sampah dengan ukuran satuan $\mathrm{kg}$ saja, sementara tidak ada harga sampah berdasarkan nilai ekonomis barang yang menguntungkan pihak pengepul sampah. Prasarana gudang menjadi kendala operasional serta pemahaman yang tidak sama akan kegiatan bank sampah seperti pemulung yang harus diatasi dengan pelatihan dan sosialisasi secara terus menerus oleh kader bank sampah terhadap warga masyarakat.

\section{DAFTAR PUSTAKA}
Hadi, Samsun. dkk. 2014. IbM Pengolahan SampahmenjadiPupuk Organik. keguruan.umm.ac.id/files/file/IbM\%20P 
UPUK\%20ORGANIK\%20FIX\%202.pdf Faizah, 2008, Pengelolaan sampah rumah tangga berbasis masyarakat, Studi Kasus di Yogyakarta, Disertasi S3, Universitas Diponegoro, Semarang.

Hari, Bayu. Dkk. 2017. PKM Pemberdayaan Karang Taruna di Desa Wonokasian dalam Pengolahan Limbah Plastik menjadi Sebuah Usaha Ekonomis Produktif.

Hermawan, Sigit. dkk. 2014. IbM Untuk Kelompok Usaha Batik Ikat Celup Tanggulangin Sidoarjo.

Joseph, K 2006, Stakeholder Participation for sustainable waste management, Habitat international Peraturan Daerah Kota Sidoarjo Nomor 6 pasal 4 tahun 2012 tentang pengelolaan sampah dan restribusi pelayanan persampahan/ kebersihan

Yulianto, Eko. dkk. 2015. IbM Pemberdayaan Karang Taruna Desa Asinan dalam Mengembangkan Potensi Wisata Alam Rawa Pening. urnal.unimus.ac.id/index.php/psn120120 10/article/view/154 